\title{
WHITEFELLA CLEANING? \\ TOPOGRAPHIES IN TRANSLATION
}

\section{Deborah Cain}

\begin{abstract}
Daniel Malone's work in the Biennale of Sydney 2004, titled A Long Drop to Nationhood, was a site-specific installation. This paper looks at the multi-layering of references to cultural forms (such as 'outhouse' and 'red hills'), aesthetic precursors (video, painting, photography, and installation practice), as well as the connections to complex cultural and political issues. Previously, Malone has appropriated corporate logos, national flags, commercial posters, advertisements, other people's art or personas, even his own name, and re-presented them in an often 'topsy-turvy' sort of way. This analogy can be paired with Germaine Greer's discussion in the Biennale catalogue extract of displacement and an Antipodean 'squattocracy'. The tension and cross-referencing between Greer's dialogue and Malone's installation create possible topographic connections. These can be opened out by the viewer's experience of the work and what Antonio Damasio describes as the recalled images that occur as you conjure up a remembrance of things past...so as to distinguish them from the perceptual variety' (1994: 96-97).
\end{abstract}

Two classic and often repeated phrases come to mind when thinking of the disorienting yet nostalgically familiar feelings I experienced on encountering Daniel Malone's installation in the 2004 Sydney Biennale. The first is from a 'modern fable' using an old form but set in 'modern times', more remembered in its 1939 filmic version than its original appearance in 1900 as an American fairytale: 'I've a feeling we're not in Kansas anymore', said Dorothy/Judy Garland to her little travel companion, the dog Toto, in The Wizard of $\mathrm{O} z$ (Fleming, 1939). This sentiment is quoted by Robert Storr (1992), in his catalogue essay for the 1991 exhibition of installation art Dislocations, which starts with the sentence 'Where are we?' and raises the idea of the museum being representative of the spatial paradigms of parallel, un-reconcilable, and allegorical worlds where things move and memory becomes blurred. The second phrase 
is from a scene in the New Zealand soap, Shortland Street on 25 May 1992: 'You're not in Guatemala now, Dr Ropata!' It speaks of a set of displacements in the global, of what might be an even more exotic and marginal locale, from a New Zealand Aotearoa perspective. In this most famous line in the Street's screen history, Nurse Carrie/Lisa Crittenden tries to assert proper procedures, and to put the 'newly arrived Dr Ropata/Temuera Morrison in his place by angrily reminding him of where he is not (see The New Zealand Film Archive 2004). These two phrases both encapsulate different issues of spatial memory and history that I want to discuss in relation to Malone's artwork. For this paper, his work is framed by these ideas in a dialogue that is, above all, about an experience of art in the Art Gallery of New South Wales, mediated by memory, popular culture, and inflections of masculinity and identity.

Malone's work, A Long Drop to Nationhood, consisted of a wall painting that wrapped around both sides of the gallery corridor, an outhouse relocated from rural New Zealand, documentation material of five framed 'import' texts on the wall, and a 'cleaning' video installed inside the exported toilet shed. Malone has said that the work was made in response to both expatri-

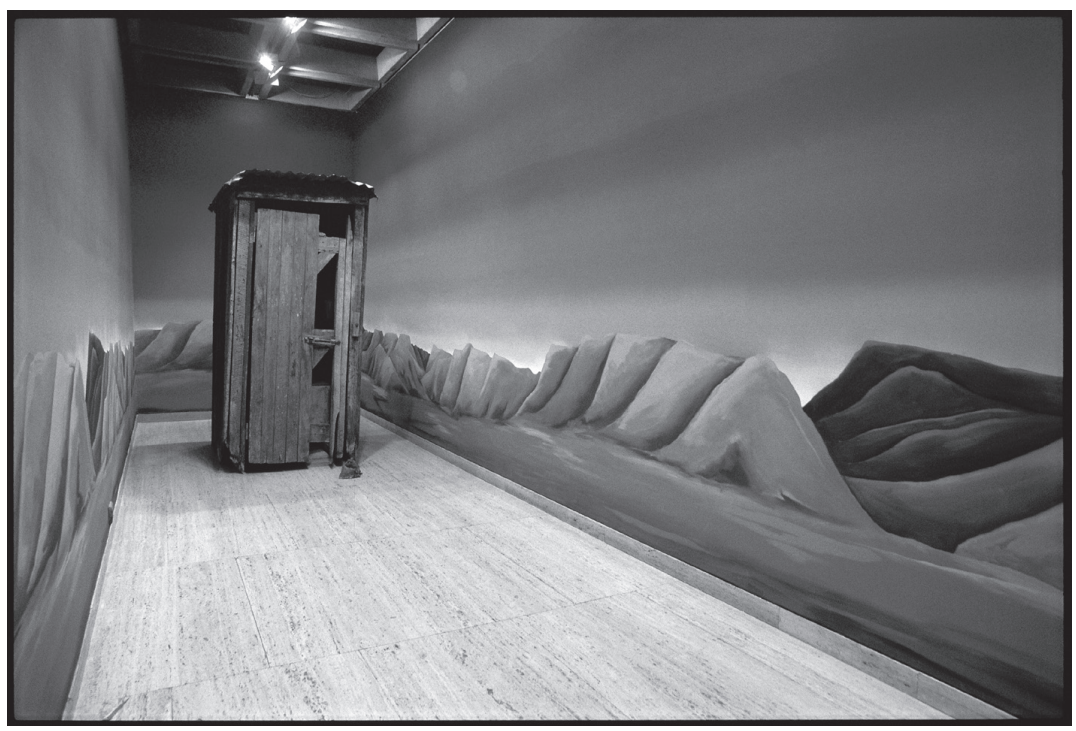

Fig 1. Daniel Malone, A Long Drop To Nationhood, 2004. Readymade Kauri wood outhouse, painted wall mural, video with sound, export/import documentation. Dimensions variable. Installed in the Art Gallery of New South Wales, Sydney, Australia. Post-Biennale catalogue image. Courtesy of the artist. 


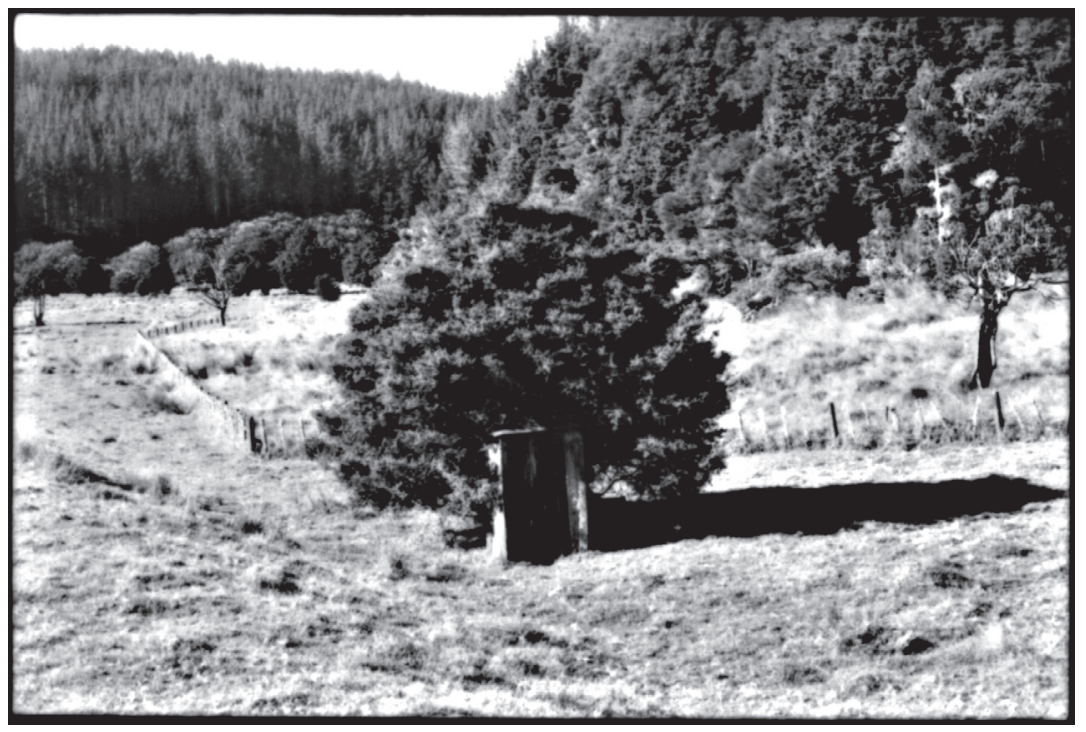

Fig 2. Daniel Malone, (Partially Covered Outhouse), In Situ, Opouteke, Northland, Aotearoa/New Zealand, 2004. Black and white photograph. Courtesy of the artist.

ate Australian - now University of Warwick Professor of English - Germaine Greer's two talks given in Auckland 2003, and to the corridor space he was allocated in the Sydney public art gallery, with its grand colonial era exterior and contrasting modernised interior.

While one of the main issues that featured in the New Zealand media when Greer visited in 2003 was her unpaid \$40 court appeal costs from 1972, after being prosecuted for using 'bullshit' and 'fuck' in public and having vowed never to return, she was here this time to discuss the health of intellectual debate in New Zealand and to give a public address. There is an obvious connection between Greer's (2003) Australian-published Quarterly Essay, in its title and the excerpts quoted in the Biennale catalogue extract, and the title of Malone's installation. Between Greer's title, 'Whitefella Jump Up - The Shortest Way To Nationhood', and Malone's A Long Drop to Nationhood, there is a sort of 'flip-flop' of ideas and references. Greer's thesis of white aboriginality can also be related to the New Zealand historian Michael King's work on race and national identity in New Zealand, as expounded in his autobiographical books, Being Pakeha: An Encounter with New Zealand and the Maori Renaissance, published in 1985, and Being Pakeha Now: Reflections and Recollections of a White Native, from 1999. Both Greer's and King's ideas have been con- 
tested in Australia and New Zealand and cannot be taken on face value, but they provide a background from which one could think through the complex issues that come out of this conjunction, and the inclusion of Greer's writing in the exhibition catalogue.

It is above all important to remember that Daniel Malone incorporates the performative, the incidental, and the evolving aspects, which sees him collect and collate the accidental in his art process (see Bywater 2003:64). His work is never truly ethnographic, although it might appear in that guise when he assembles a montage of material; but this doubling always inter-references a synthesis of art and media images or information. Nevertheless, the work Malone contributed to the Wellington Prospect 2004 exhibition, Mythopoeia - There and Back Again, was described by an online curator, in an interesting grab bag of terms, as being a 'cultural ethnographer, scavenger, archivist, producer and arranger' (see Telecom Prospect 2004). On a metaphoric level, seeing that it was an installation in an art gallery, the mistake of reading the work as ethnographic is a problem faced by the relation of a poorly informed viewer to the thing viewed, and mediated by a popularist cultural supposition of difference. Ilya Kabakov makes a similar point in a conversation with Robert Storr: an audience encountering his installation might see garbage and dirt as an ethnographic depiction merely because they assume this is what Russia is like (Storr 1995). It can also be applied, for example, to how Shirin Neshat's photographs were often presented in the publicity for her 2004 exhibition in Auckland. We are considering Malone's artwork here at a time when various countries grapple with ongoing notions of local collective identities in a globalised world, and what remains 'exotic' to them.

Taking Germaine Greer's notions of indigeneity and of writing (based on what she called 'loo-length chapters'), the outhouse was a metaphor that came up, in connection to her description, as a vernacular form of architecture common to both New Zealand and Australia. This structure led Malone to recall the image from the artist Tracey Moffatt's film Night Cries: A Rural Tragedy from 1989. Central to the narrative of this disquieting film is the complex relationship between an elderly white woman/Agnes Harwick and her middleaged aboriginal daughter/Marcia Langton. The scene Malone re-configures for his art piece is the theatrically staged setting of the outside tin-shed toilet, to which the exasperated daughter has to take the skeletally shrinking mother, in a wheel chair. Its surrounding landscape of outback Australia, in the set design by Stephen Curtis for the film, is characteristic of the high-keyed saturated colours used by the popular watercolourist Albert Namatjira - of the Western Arrernte people in Central Australia (1902-1959) - painting his 
country in the 1930 s to 1950 s using a 'Western' technique which is not 'quite right' and previously often considered kitsch. Earlier reception to that artist's work has been divided between attributions of 'low artistic merit' and as being of institutional value for 'political, sociological, and journalistic' reasons (Daniel Thomas, as cited in Burn and Stephen 1991:61).

Writing for the 1993 catalogue of the ninth Biennale of Sydney entitled The Boundary Rider, Ian Burn pointed to the artificiality of Moffatt's studio-filmed work Night Cries, as a hybridization that deliberately affronted the viewer. The 'painted rural landscape with its reference' back to Namatjira, was no 'mere backdrop', but a landscape as 'a sign (of a sign)' that 'infiltrates and charges the physical-temporal space between actors', where Namatjira was able to 'colonise the intense visuality of the film' by re-authorising it (Burn 1993:32). In its inherently surreal imagery that Meaghan Morris has described as a 'glowing aestheticized "desert" (1998:256), there is an element of menace and a refusal to explain itself, which runs through much of Moffatt's work. Re-creating the image-still in the Art Gallery of New South Wales in 2004, Malone references the issues of Aboriginality and the murky history of nationalism inherent in the work, over a decade on from when Moffatt made her film. By coincidence, the critical reflection provoked by the artwork in the early 1990 s, and the context in which Burn's essay emerged, can be measured against current silence and visibility. It begs the question, in a view from outside Australia: 'how have things changed'?

The concept of 'the southern', in its variations, was taken up by the 2004 Sydney Biennale curator Isabel Carlos in her catalogue essay, On Reason and Emotion (2005). As a starting point for the exhibition, she takes the neurologist António Damásio's research into the emotional as a component of human intelligence and therefore the mind, and of reason. But, she suggests, emotion, as a cliché in Western societies, is popularly associated with the south and the body. Although all countries have their own south, Australia, in-itself a southern country, became entangled with ideas of the antipodes and 'Terra Australis' in the processes of its naming (see Ryan 2004). Notions of the 'south' and its bodily dimensions influenced Daniel Malone in his conceptual process. The architectural and spatial elements of his installation engage with this on several levels in an open-ended way. The relationships between the building and the landscape, its installation and location, are part of this, and are inclusive of Greer's (2003) discussion questioning 'Terra Nullius' and the emotional rationalization of a 'colonial emptiness'.

In the landscape iconography of the desert, which became 'part of a mytholo- 
gised idea of Australia' in the work of artists like Russell Drysdale c.1940s, life in the outback regions was conceived of as harsh and isolated (Burn 1991:78). At the same time popular publications like the novels of Ion Idriess and pictorial magazines such as Walkabout, promoted a wider circulation of images of an area that was largely unknown to urban Australians. Meanwhile, Ian Burn saw the engagement of artists like Sydney Nolan with the subject as, to a large degree, challenging the earlier nationalism of the heroic pastoralist views and the 'bush ethos' of the Heidelberg school or the pre-war Arthur Streeton, by introducing modernist practices and non-threatening landscapes (Burn 1991:78-81). While paying attention to both his European and Australian predecessors, Nolan was finding his own idiom that included experiments with cubist space while retaining the blue of Streeton's Fire's On! Lapstone Tunnel (1891), and naturalistic pictorial space for the depiction of the cultural signifier of a so-called Australian 'vastness' (Burn 1991: 69).

As part of his Outback series, Nolan's Outhouses of 1949 shows his vision of the 'Interior' landscape, and the flimsy corrugated iron sheds inhabited by 'aboriginals on the margins of prosperous white society'. They can be compared with the pubs, stores, and mining structures he observed on his travels in the late 1940 s and early 1950s, with the tent and the shed becoming recurrent emblems of the miner, the explorer, and the transience of existence on the dusty landscape, in contrast to the relative comfort and affluence of city living in the 1950s. A photograph taken by Nolan similar to his Outhouse painting, and published in Cynthia Nolan's book Outback (1962), shows how Nolan took photographs on his travels to assist his memory for the paintings. The Durack Range (1950) reflects an aerial view of the Kimberley in the North West of Australia and is typical of the topographic paintings that brought him popularity. The desert, in its extreme, was seen as the essence of the Australian landscape, symbolising the vastness of the island continent. With a 1965 painting, Riverbend (nine panels), Nolan reached a point where he decided that he could not be a 'European', and that the painting Desert Storm (1966) represented for him 'a proper, an Antipodean, emblem: it expresses both place, and a situation of soul' (Clark 1987:159). Though it is devoid of figurative representation internal to it, the spectator becomes involved with the work in such a way as to become the figure in relation to the land. In terms of this involvement of the spectator, we can also consider Nolan's interest in film and stage-set design here, in comparison with the work of other 1950 artists elsewhere.

As an analogy, Malone's installation brings to mind the import/export of contemporary national politics across-the-ditch, where the current leader of the New Zealand opposition party, Don Brash, has been accused of imitating the 
Australian Pauline Hanson's racist diatribe. In a recent public lecture rhetorically titled 'Are we all New Zealanders now?' Dr Ani Mikaere challenged the '...pakeha quest for indigeneity' and critiqued media comments made by the likes of the Minister of Education Trevor Mallard, ${ }^{1}$ Don Brash, ${ }^{2}$ and Michael King. ${ }^{3}$ In the same month expatriate New Zealander and University of Copenhagen professor, Michael Jackson, gave a public lecture in Auckland titled 'Quandaries of Belonging: Some Home Thoughts from Abroad', where he spoke about certain people living double 'schizoid' lives of displacement and multiple belongings (Jackson 2004).

Likewise, the Lebanese-born Australian anthropologist Ghassan Hage, writing in the late 1990s, has discussed how a 'White fantasy' has:

pathologised all attempts of non-Whites - ethnics and Aboriginals - to engage in independent political and managerial decision making: from the 'branch stacking' of political parties, to lobbies and industries, to the 'mishandling of government funding' by non-White organizations (Hage 1998:240).

Thus, he argues, there is a perceived need for government of 'ethnic and Aboriginal objects' to restore national order through supervision by White technocrats (Hage 1998:18). His discussion centres around an ambivalence of what he calls White multiculturalism (citing fellow Sydney academic Ien Ang) towards tolerance and acceptance that is reflected in a discourse of inclusion and exclusion, and where many non-Anglos equally define themselves through a 'White nation' fantasy (Hage 1998:18). The outcome of this is a positioning of the migrant in a "liminal space of "not too excluded, but not too included either"', and institutionalised by a White multiculturalism (Hage 1998: 243).

Integration, Hage points out, has occurred in Australia independent of institutional and government ideology. But alongside this lived reality of different individuals in Australia, policy makers have legislated, and then subsequently moved away from, a monocultural mould. In contrast to the interaction on the everyday level, Hage cites the scenario of 'specific social and cultural backgrounds' where some Australians:

have not been able to incorporate into their national fantasy space the migrant presence that has resulted from the immigration of the 1970s, 1980s, and 1990s (Hage 1998: 211).

His ethnographic information was collated from emotional interviews where 
White Australians articulated their experience of loss, in 'various aspects of the discourse of decline', being displaced in their sense of 'governmental belonging to the nation' and hope in social and economic mobility previously offered by Anglo-ness (Hage 1998: 211).

In relation to these cultural and political issues and the aesthetic processes utilised for the art piece, the metaphors of 'outback' and 'outhouse', then, as symbolic spaces in the conceptualisation of a previous homely white nationalism re-enacted in the museum - via an appropriated image-still taken from another artist's already filmic pastiche - re-appears as such in Malone's installation with its multi-layered possible references. Contributing to a 'fairytale' view of Australia in the trope of 'the red hills' and 'the red center' of 'outback' Australia, the fantasy is identifiable in its popularist symbolism, but has been further digitally processed by Photoshop into yet another artist's topographic form, that of Colin McCahon, and by inference another possible nationalism, of 'green' New Zealand. The other symbol, the rural toilet from a New Zealand farm, is also a general attribute of urban development and the shift of the outside toilet to the inside of the modern home in the post-war years of the 1950s. This would allow a recollection, and sublimation, of a period prior to the contemporary acceptance/non-acceptance of diversity - that is, from the period when Aboriginal Australians did not have citizenship rights in their own country (see Beckett 2000: 85) and older historic Asian migrants could be shown that their self-definition as Australian could be challenged by a pro-White conception of nation. This was therefore when the 'outback' of 'the north' was a place to be controlled, supervised, and feared. Like the old fear of Asia, the contemporary fear of being 'swamped by Asians' is played out against this backdrop. The 'homely' aspect of the familiar 'outhouse' and 'red hills' is in stark contrast to the 'unhomely' aspect of the uncontrolled 'outback' of the 1940s-50s, in particular, the World War II years and the fear of invasion.

Popularist writing in the 1970s of places that were considered 'no longer the unreachable back-of-beyond of Australia', as the then Perth-based journalist Athol Thomas described the northern part of the country, includes the experience of local born James Chi. His father, John Chi, was considered 'one of Broome's most respected citizens' and was well known as 'the first pearler to bring luggers from Cossack to Broome' in the late 180os. But old newspaper clippings kept by Chi from the 1940 os tell of the Australian Government's policy of interning Australian Asians during the war with Japan. They name and make reference to Chi, indicating how he was unfairly imprisoned for four years and taken a long way from home, to South Australia because his mother was Japanese. Chi, after his release, returned to Broome because 'It was my 
town and I came back' (Thomas 1977:28). His son later wrote the musicals Bran Nue Dae in the 1980 os (performed in the 1990 Perth festival), and Corrugated Road (1996) which, along with the music of Yothu Yindi and the dance group Bangarra, have been received in Australia as part of a so-called 'renaissance of Indigenous culture' appealing to Indigenous and non-indigenous audiences alike (Meekison 2000:367). Described as a 'biography of a generation' Jimmy Chi's musicals dealt with history of his own era, its dislocations and its effects, while Corrugated Road, taking the stories and music further, was considered more surreal in its drama and chaotic plot (Bibby 2000:356). The incorporation of these different artists under a rubric of Aboriginality for the national good of mainstream art, allowing it to be also 'Australian' and 'antipodean', requires their essential doubleness, and is a position that has often been critiqued because of its institutionalised appropriation (see Meekison 2000:367; Burn 1993:31).

It is an earlier popularist writing, the hagiography of Mary Durack's (1959) story of a Kimberley cattle family and their 'aboriginalisation' (Kings in Grass Castles, made into a television drama, 1997), as taken up by Germaine Greer for an example of 'topsy-turvy' antipodean behaviourism (Greer 2003:66), that is crucial to the Moffatt image-still appropriated by Malone. The 'loathing of the outback' and destructive behaviour, the 'boundary riders' (to quote the writer Henry Lawson's Joe Wilson) (Greer 2003: 6), and the contradiction of the 'heart of the country' being considered 'dead', as questioned by Thomas Keneally in his 1984 essay 'On Being Australian', and mentioned by Greer, can also be considered here (Greer 2003:7).

It was my early 1970 experience of Sidney Nolan's Desert Storm (1966) that I recalled when I walked into the Malone installation in Sydney. Subsequently, I remembered walking along the gallery corridor in 2000, when Sophie Calle's Suite Vénitienne (1980), consisting of 55 black and white photographs and 23 texts with 3 maps, had been installed along those same walls. Her fascination with the intrigue of urban life was in stark contrast to the landscape and nostalgic, but empty, presence of the contemporary popular experienced in A Long Drop to Nationhood. One can consider the title of Bruce Nauman's Office edit II with color shift, flip, flop, \& flip/flop (Fat Chance John Cage), Mapping the Studio (2001), included in the 2004 Biennale. But also, what comes to mind, is my recollection of looking through the door/gallery wall, as if through Sartre/Lacan's keyhole, to peer at the image of the female torso, lamp and faux waterfall of the scene remade by Richard Baquié of Marcel Duchamp's Etant Donnés, and on display in the Art Gallery of New South Wales' Body exhibition in 2000. ${ }^{4}$ 
Finally, we conclude with the awry figure of the slightly sad outhouse of Malone's installation, with its leaning and dishevelled appearance, having made its journey across 'the ditch' between New Zealand Aotearoa and Australia, forlornly conjuring up ghosts and a laugh or two. This shed, or outhouse, in its topological poignancy almost flips between the heimlich (of its shed-ness, 'every man should have one in his backyard') and an unheimlich manifestation - its leaning awkwardness, the broken door (which is not quite the keyhole view that positions the voyeur in his/her posed public/private dialectic of the gaze) - through which we see not the 'in-reality' incomplete wax torso of a generic woman in the dioramic landscape, but the artist in his studio in Auckland busily cleaning his shed for export. The curtain is pulled back on the grand fantasies of nationalisms, implicit masculinities, and, the discrete art object. Like in the Wizard of $\mathrm{O} z$, we see the little man behind, in all his frailty. As a play of metaphor and metonymy, Malone's 'outhouse and hills' installation piece, A Long Drop To Nationhood, could be re-named 'whitefella cleaning'.

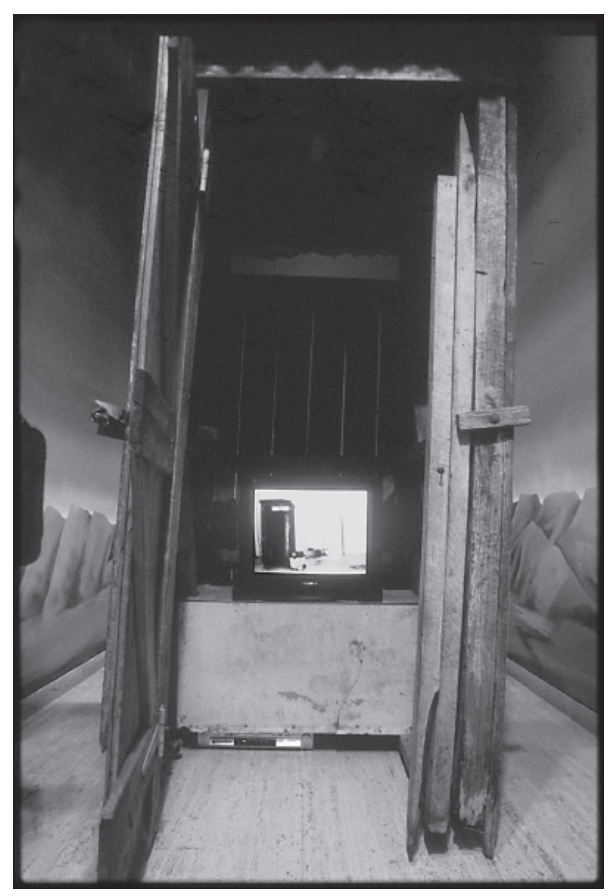

Fig 3. Daniel Malone, Detail image of the 'Toilet Cleaning Performance', 2004. Video with sound, (detail from installation). Courtesy of the artist. 


\section{ACKNOWLEDGEMENTS}

I would like to acknowledge both Daniel Malone's contribution in providing the images, and his critical engagement with this paper.

NOTES

1 For example, Mallard's appealing to Maori for 'trust' (see Mikaere 2004).

2 Brash's now infamous Orewa speech. For a detailed discussion of this, see Barber 2004 .

3 King's seeking a 'mutuality of respect'. This has also been discussed in-depth by Michael Goldsmith (2004).

4 Richard Baquié, 'Sans Titre Etant Donnés: $1^{\circ} \mathrm{La}$ chute d'eau $2^{\circ} \mathrm{Le}$ gaz d'éclairage (Untitled. Given: 1. The Waterfall 2. The Illuminating Gas)', 1991 installation (Bond 2000).

\section{REFERENCES}

Barber, K. 2004 'Treaty Rights and Race-based Funding: The Politics of Resentment and the New Racism, paper presented in the Anthropology Department Seminar Series, University of Waikato, Hamilton, 21 May.

Beckett, J. 2000 'Art and Culture in Unsettled Australia', in S. Kleinert and M. Neale (eds) The Oxford Companion to Aboriginal Art and Culture, Melbourne: Oxford University Press: 81-92.

Bibby, P. 2000 'Power Country', in S. Kleinert and M. Neale (eds) The Oxford Companion to Aboriginal Art and Culture, Melbourne: Oxford University Press: $354-356$.

Bond, A. 2000 Body, exhibition catalogue, Sydney: Bookman.

Burn, I. 1991 'Sydney Nolan: Landscape and Modern Life', in I. Burn (ed) Dialogue: Writing in Art History, Sydney: Allen \& Unwin: 67-85.

Burn, I. 1993 'The Metropolis is only Half the Horizon', in A. Bond (ed) The Boundary Rider: the 9th Biennale of Sydney, Sydney: Biennale of Sydney Ltd: $30-32$. 


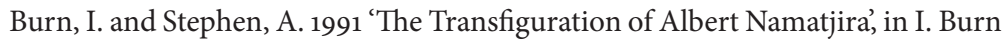
(ed) Dialogue: Writing in Art History, Sydney: Allen \& Unwin: 52-66.

Bywater, J. 2003 'Daniel Malone is Feeling Himself', The New Zealand Listener 189 (3296): 64.

Carlos, I. 2005 Biennale of Sydney 2004: On Reason and Emotion, catalogue essay, Distributed Art Publishers, Inc.

Clark, J. 1987 Sydney Nolan: Landscapes and Legends, Melbourne: ICCA National Gallery of Victoria.

Damasio, A. Descartes Error: Emotion, Reason, and the Human Brain, New York: HarperCollins, 1994.

Durack, M. 1959 Kings in Grass Castles, London: Constable.

Fleming, V. (director) 1939 The Wizard of $\mathrm{Oz}$ [motion picture], United States: MGM.

Goldsmith, M. 2004 'Being European: Mapping the Language of Racialism in New Zealand', paper presented in the Anthropology Department Seminar Series, University of Waikato, Hamilton, 14 May.

Greer, G. 2003 'Whitefella Jump Up - The Shortest Way to Nationhood', Quarterly Essay Issue 11.

Hage, G. 1998 White Nations: Fantasies of White Supremacy in a Multicultural Society, Annandale, Nsw: Pluto Press.

Jackson, M. 2004 'Quandaries of Belonging: Some Home Thoughts from Abroad', paper presented at The University of Auckland, 30 November.

King, M. 1985 Being Pakeha: An Encounter with New Zealand and the Maori Renaissance, Auckland, NZ: Hodder and Stoughton.

King, M. 1999 Being Pakeha Now: Reflections and Recollections of a White Native, Auckland, NZ: Penguin. 
Mikaere, A. 2004 'Are We All New Zealanders Now? A Maori Response to the Pakeha Quest for Indigeneity’, Bruce Jesson Memorial Lecture, presented at The Auckland University, 15 November.

Meekison, L. 2000 'Bangarra Dance Theatre', in S. Kleinert and M. Neale (eds) The Oxford Companion to Aboriginal Art and Culture, Melbourne: Oxford University Press: $367-369$.

Moffatt, T. (director) 1989 Night Cries: A Rural Tragedy [motion picture], Australia: Ronin Films.

Morris, M. 1998 'White Panic or Mad Max in the Sublime', in Kuan-Hsing Chen (ed) Trajectories: Inter-Asia Cultural Studies, London and New York: Routledge: 239-262.

The New Zealand Film Archive 2004 www.filmarchive.org.nz/services/collections_images.html

Nolan, C. 1962 Outback, London: Methuen.

Ryan, T. 2004 'The First “Australians”: Genealogy of a Naming', paper presented at the Eighteenth Century Studies Conference, Canberra: National Library of Australia, 20-22 July.

Storr, R. 1992 Dislocations, catalogue essay, New York: Museum of Modern Art.

Storr, R. 1995 'An Interview with Ilya Kabakov', Art in America 83 (1): 60-70.

Telecom Prospect 2004: New Art New Zealand, online catalogue (curator E. Bugden) 2004 'Daniel Malone - Mythopoeia - There and Back Again' www. telecomprospect2004.org.nz.

Thomas, A. 1977 Bulls and Boabs: Kimberley People and Places, Adelaide: Rigby. 